\title{
Gene expression response to ascorbic acid in mice implanted with sarcoma S180 cells
}

\author{
Nina Mikirova ${ }^{\S *}$ and Ruth C. Scimeca ${ }^{\S}$ \\ Riordan Clinic, 3100 North Hillside, Wichita, KS, USA \\ ${ }^{\S}$ These authors contributed equally to this work
}

\begin{abstract}
In recent years, increasing numbers of studies demonstrated that high-dose ascorbate, which can be achieved by intravenous infusion, has cytotoxic effects on cancer cells in vitro and in vivo. There are many hypotheses of anti-cancer mechanisms of high dose ascorbate including a pro-oxidative mechanism, inhibition of angiogenesis and inflammation, enhancement of the anticancer effect of chemotherapy and reduction of chemotherapy-induced side effects. In addition, in recent years there were studies showing that ascorbic acid has effect on gene expression and epigenetic phenomena. In our study we analyzed, by using animal model, the effect of pharmacological concentrations of ascorbic acid on several gene expressions involved in tumorigenesis. To test the effects of ascorbic acid on gene expression, we treated mice with two different concentrations of ascorbic acid after intraperitoneal administration with sarcoma S-180 cells. The injected doses of ascorbic acid were equivalent to $15 \mathrm{~g}$ per $70 \mathrm{~kg}$ human and $50 \mathrm{~g}$ per $70 \mathrm{~kg}$ human. Tissue from tumors, liver and kidney was obtained from mice at the end of three weeks of treatment. The gene expression analysis was computed by real time PCR. The results showed significant difference in expression of gene $\mathrm{p} 53$ ( $\mathrm{p}<0.02$ ) in tumor tissue between treated and non-treated groups, and reduction of p53 gene expression by size and spreading of tumors. Ascorbate therapy significantly increased expression of NRF2. The experimental data showed that the maximum ascorbate dosage reduced expression of the tumor promoting gene HIF. The dependence of gene expression on the size of tumors was found for P53, HIF and NF-kB. In summary, the results of our study demonstrated that ascorbate therapy had a significant effect on the expression of several genes relevant to the development or inhibition of cancer. Reduced expression of tumor promoting genes as HIF and increased expression of tumor suppression genes such as p53 support the hypothesis that ascorbic acid can act as a potential agent for the suppression of tumor development.
\end{abstract}

\section{Background}

Ascorbic acid (AA, ascorbate, vitamin $\mathrm{C}$ ) is an essential water soluble antioxidant that has been studied for decades for its potential role in preventing chronic diseases [1]. Ascorbate plays a role in limiting inflammation, regulating cytokine production, and boosting the immune system [2-8]. It has a variety of properties that have generated interest in using it against cancer [9-13]: it enhances natural killer cell activity [14,15], increases collagen synthesis [16], inhibits capillary tubule formation (angiogenesis) [17,18], reduces inflammation in cancer patients [3], at millimolar concentrations, shows cytotoxicity against cancer cells [19-24] and the ability to reduce tumor growth in vivo [25-34]. Clinical trials to date [35-40] indicate that high dose (on the order of ten to 100 grams) intravenous ascorbate therapy can enhance anti-cancer effects of chemotherapy and improve quality of life in cancer patients.

Recent studies indicate that vitamin $\mathrm{C}$ may have important effects on gene expression. For example, hypoxia inducible factor 1 (HIF-1) may induce the expression of more than sixty genes, including those coding for vascular endothelial growth factor (VEGF), erythropoietin (Epo), and nitric oxide synthase-2 (NOS-2); transcription and translation of these genes yields proteins that play key roles in angiogenesis, regulation of glucose metabolism, cell survival, and cell proliferation [41-44]. Decreased HIF-1 activation is associated with increased disease free survival in patients with cancer. The HIF-1a subunit regulates expression of Bcl-2 family proteins, which in turn protect cells from reactive oxygen species (ROS) induced apoptosis [45-50]. Since the induction of HIFs may be mediated by ROS, antioxidants such as vitamin C may inhibit HIF-1 and HIF-1a expression; this is supported by experimental studies [45-51]. Vitamin $\mathrm{C}$ may also act on HIF-1 expression by inhibiting the expression of Nuclear Factor kB (NF-kB) genes. NF-kB is involved in inflammation and tumor development [52-55]. Ascorbate has been shown to inhibit the expression of NF-kB [52,55-58].

The anticancer effect of ascorbate may be in part due to its ability to suppress specificity protein (SP) transcription factors (such as Sp1, Sp3, and Sp4) [59]. Sp-regulated genes are involved in cancer proliferation (via hepatocyte growth factor receptor, epidermal growth factor receptor, and cyclin D1), survival (via survivin and Bcl-2) and angiogenesis (via VEGF and its receptors) [59-62].

Ascorbate may also suppress tumor growth through modulation of p53 [63-65]. The gene for p53 is particularly important in regulating cell proliferation, cell cycle progression, DNA repair, senescence and apoptosis in tumor cells [66-70].

Other genes of importance to cancer that are possibly affected by millimolar levels of ascorbate include: DNA methyltransferase (DNMT1), which is responsible for maintaining DNA methylation and in silencing tumor susceptibility genes [71-76]; human telomerase

Correspondence to: Nina Mikirova, Riordan Clinic, 3100 North Hillside, Wichita, KS, USA; E-mail: nmikirova@riordanclinic.org

Key words: high dose ascorbic acid, gene expression, animal study

Received: March 15, 2016; Accepted: March 23, 2016; Published: March 26 , 2016 
reverse transcriptase (TERT), which regulates telomere length, can promote tumor development, increases the anti-apoptotic capacity of cells, enhances DNA repair [77] and nuclear factor erythroid derived 2 (Nrf2), which has anti-apoptotic effects and may therefore protect cancer cells [78-79]. Ascorbate has been shown to target the expression of these genes (promoting p53 while inhibition expression of the others) in tumor cells [57-59,80], which in turn shifts cells toward the sub-G1 fraction.

In addition, gene expression studies in vivo and in vitro have suggested that the carcinostatic effect induced by high dose concentration ascorbic acid occurred through inhibition of angiogenesis. In the study [25] the expression of three angiogenesisrelated genes were inhibited by 0.3 times in Fibroblast Growth Factor (FGF2), 7 times in VEGF and 4 times in Matrix Metallopeptidase 2 (MMP2) of the groups with higher survival rates.

The purpose of the present study is to examine how high dose AA therapy affects the expression of the several genes in vivo, using the murine S-180 tumor model, in order to gain more insight into ascorbates potential mechanisms of action against tumors.

\section{Methods \\ S180 Cell line}

The S180 mouse sarcoma cell line was obtained from ATCC (Manassas, VA) and cultured in $75 \mathrm{~cm}^{2}$ flasks with $20 \mathrm{~mL}$ of RPMI1640 media supplemented with $10 \%$ fetal bovine serum (ATCC) and $100 \mathrm{U} / \mathrm{ml}$ Penicillin-Streptomycin (Sigma Aldrich, St Louis MO) at $37^{\circ} \mathrm{C}$ in a $5 \% \mathrm{CO}_{2}$ atmosphere.

\section{CD-1 Mice}

CD-1 female mice from Charles River were kept under standard conditions of temperature $\left(22^{\circ} \mathrm{C}\right)$ and light $(12 \mathrm{~L} / 12 \mathrm{D})$ and had access to water and food (Laboratory Rodent Diet 5001, LabDiet St. Louis MO). Principles of laboratory animal care following IACUC procedures were applied, and all experimental protocols were approved by the Ethics Committee of WSU (Wichita, KS). Mice were given seven days to acclimate upon arrival, and were weighted and identified on the eight day. Weight was tracked weekly thereafter and general condition was recorded three times a week.

\section{Tumor Inoculation and ascorbate therapy}

For tumor growth and gene expression experiments, mice were injected IP with S180 cells. S180 cells were collected by Trypsin detachment and washed two times by PBS. After detachment $1.5 \times 10^{6}$ cells diluted in $100 \mu \mathrm{l}$ PBS were implanted subcutaneously into the right flank of mice using $25 \mathrm{G}$ needles. One week after tumor inoculation, ascorbate therapy was commenced via injection. Two AA doses were tested: "Low AA" was $0.214 \mathrm{mg}$ AA per gram mouse mass (equivalent to a $15 \mathrm{~g}$ dose in a $70 \mathrm{~kg}$ human, a typical starting dose in intravenous ascorbate therapy), and "High AA" $0.714 \mathrm{mg}$ AA per gram mouse mass (equivalent to a 50 gram dose in a $70 \mathrm{mg}$ human, a maximum dose typically used in intravenous ascorbate therapy). Ascorbate injections were administered three times per week. Animals were divided in five groups of eight mice each: above.

Group A) Tumor-free mice given the Low AA dose as described

Group B) Tumor-free mice that did not receive ascorbate therapy (Negative Control)
Group C) S180 inoculated mice given the Low AA dose as described above.

Group D) S180 inoculated mice given the High AA dose as described above.

Group E) S180 inoculated mice that did not receive ascorbate therapy (Positive Control)

Tumor bearing mice were euthanized after three weeks of ascorbate therapy.

\section{Necropsy and gene expression analysis}

Organs (tumors, livers and kidneys) were resected immediately post-euthanasia. Tumors were measured and weighted at euthanasia. Samples of kidney, liver and tumor were collected and kept at $-80^{\circ} \mathrm{C}$ for RNA extraction. RNA extraction and qRT-PCR analysis were carried out as follows. Tissues were minced and then passed through 26 gauge needles to disaggregate. RNA was extracted using TriReagent (SigmaAldrich, Hercules CA) according to manufacturer's instructions. Total RNA quality and quantity were evaluated using Nanodrop ND2000 (Thermo Scientific, Pittsburg PA), and $0.5 \mu \mathrm{g}$ total RNA were converted to cDNA using iScript RT super-mix in the CFX96 RealTime PCR Detection System (Bio-Rad, Hercules, CA, USA). PCR reaction conditions consisted of an initial 30 seconds denaturing at $98^{\circ} \mathrm{C}$, followed by forty cycles of denaturing at $95^{\circ} \mathrm{C}$ for 10 seconds, annealing at $56^{\circ} \mathrm{C}$ for 15 seconds and extension at $60^{\circ} \mathrm{C}$ for 15 seconds, followed by melt-curve analysis. cDNA was quantified using the Nanodrop ND-2000.

A total of $250 \mathrm{ng}$ cDNA was used to analyze gene-specific oligonucleotide primers (Table 1) with the SsoAdv Universal SYBR GREEN Kit. A dissociation curve was run at the end of the reaction to ensure that only one amplicon was formed and that the amplicons denatured consistently in the same temperature range for every sample. cDNA levels were normalized against the reference housekeeping genes RPS13 and TBP (Table 1) using the genNorm method. The relative expression of a target gene was computed, based on its real-time PCR efficiencies $(\mathrm{E}=2)$ and the cycle threshold $(C \mathrm{t})$ difference $(\Delta)$ of mean control versus each sample ( $\Delta C$ t control-treatment) using RPS13 and TBP as the reference housekeeping genes.

\section{Statistical analysis}

The comparisons of gene expression between different experimental groups of mice and size of tumor were carried out using the statistic software Kaleidagraph and Systat software (Inc. Chicago, USA). Data are presented as medians with IQR and mean \pm SE. Differences in mean values were considered significant at the level of $95 \%(p<0.05)$ (Mann-Whitney U test). The $2^{-\Delta \Delta \mathrm{Ct}}$ method was used to calculate the differences of the expression level of genes [81].

\section{Results and discussion}

\section{Tumor growth and necropsy findings}

S180 inoculated animals formed abdominal tumors in all cases except for four mice in Group C (Low AA dose). These four animals were excluded from subsequent analysis. In all other cases, S180 inoculations lead to rapid tumor development and noticeable decrease in animal well-being. One of the mice in Group D (High AA) developed an encapsulated tumor on the left kidney, coinciding with an enlargement of the right kidney. Two mice in Group C and two in Group D developed metastasis in thorax. We did not find any other 
Table 1. Oligonucleotide primers used for gene expression measurements in real time RT-PCR.

\begin{tabular}{|c|c|c|c|}
\hline $\begin{array}{l}\text { GenBank } \\
\text { Accession Number }\end{array}$ & Symbol & Description & Primers \\
\hline AY521463.1 & NFkB & Mus musculus nuclear factor kappa B & $\begin{array}{l}\text { MmNFkBF: gagcaaccaaaacagagggg } \\
\text { MmNFkBR: cctgctgttacggtgcatac }\end{array}$ \\
\hline NM_010066.4 & DNMT1 & Mus musculus DNA methyl transferase 1 & $\begin{array}{l}\text { MmDNMT1F: cccaaggaagagtcggaag } \\
\text { MmDNMT1R: tcctcetttgatttcegcet }\end{array}$ \\
\hline NM_010431.2 & HIF-1a & Mus musculus hypoxia inducible factor 1 & $\begin{array}{l}\text { MmHIF1F: tcagcatacagtggcactca } \\
\text { MmHIF1R: aagggagccatcatgttcca }\end{array}$ \\
\hline AB020317.1 & $\mathrm{p} 53$ & Mus musculus tumor protein 53 & $\begin{array}{l}\text { Mmp53F: acagtcggatatcagectcg } \\
\text { Mmp53R: gcttcacttgggecttcaaa }\end{array}$ \\
\hline NM_009354.1 & TERT & Mus musculus telomerase reverse transcriptase & $\begin{array}{l}\text { MmTERTF: tcgaacagcaaaccaacagg } \\
\text { MmTERTR: tccacatcagttcctgcagt }\end{array}$ \\
\hline NM_00102520.3 & VEGFA & Mus musculus vascular endothelial growth factor A & $\begin{array}{l}\text { MmVEGFF:gctgtaacgatgaagccctg } \\
\text { MmVEGFR: cgctccaggatttaaaccgg }\end{array}$ \\
\hline NM_026533.3 & RPS13 & Mus musculus ribosomal protein $\mathrm{S} 13$ & $\begin{array}{l}\text { MmRPS13F: tcctcaagtccaaaggcctt } \\
\text { MmRPS13R: cagaggctgtggatgactca }\end{array}$ \\
\hline NM_013684.3 & TBP & Mus musculus TATA box binding protein & $\begin{array}{l}\text { MmTBPF: tcctcaagtccaaaggcctt } \\
\text { MmTBPR: cagaggctgtggatgactca }\end{array}$ \\
\hline
\end{tabular}

significant pathological change in liver or kidney of tumor-bearing mice.

The weight of mice during the experiment was measured each week. Tumor-free mice (Group B, "Negative control") grew at a relatively steady rate of roughly 0.2 grams/day. In the tumor-bearing animals (Groups C, D, and E), mouse weight dipped noticeably (14\%$20 \%$ ) during the first week of therapy, and then rose rapidly to roughly match that of the tumor-free mice. Intraperitoneal cancer progression in each group was measured 21 days after tumor cells injections. The graphical presentation of the weight of the tumors for the each group and representative images of the tumors are presented in Figures 1a and 1b. Only animals that developed tumor are included in Figure 1a.

For untreated mice, the mean tumor volume was $530 \pm 162$ (SE) $\mathrm{mm}^{3}$ while the mean volumes for treated mice were $396 \pm 105$ (SE) $\mathrm{mm}^{3}$ for the Low AA dose and $502 \pm 138$ (SE) $\mathrm{mm}^{3}$ for the High AA dose. There was no statistically significant difference between these averages, suggesting that the ascorbate treatments did not affect tumor size in this model. The reason for this may be that the injected number of S180 cells was high that resulted in fast progression of disease, growth of tumor and deterioration of animals' conditions. Due to animals' conditions experiment was stopped 3 weeks after tumor cell injections.

\section{Gene expression on tumor tissue}

RNA was isolated from tumors, livers and kidneys of each mouse and analyzed as described above. Gene expressions in tumors normalized on the housekeeping genes are presented in Figure 2 and Table 2 and, while a box plot of gene expression levels for these genes for two groups of mice (all treated and positive control-non treated) is shown in Figure 3.

The HIF gene is important in expressing proteins necessary for tumor angiogenesis, was down-regulated in tumors of mice given the High AA dose of ascorbate therapy compared to positive control (Figure 2). This was not statistically significant $(p=0.28)$ but suggests that further study is warranted. Measured levels of the VEGF gene, the gene for a key angiogenesis promoter, were too low to draw any conclusions from. This was also true for the NF-kB gene, where low levels were obtained and no significant difference between groups was observed.

Expression of the p53 gene, a key regulator of apoptosis that is mutated in many tumor cell types, was enhanced roughly two-fold

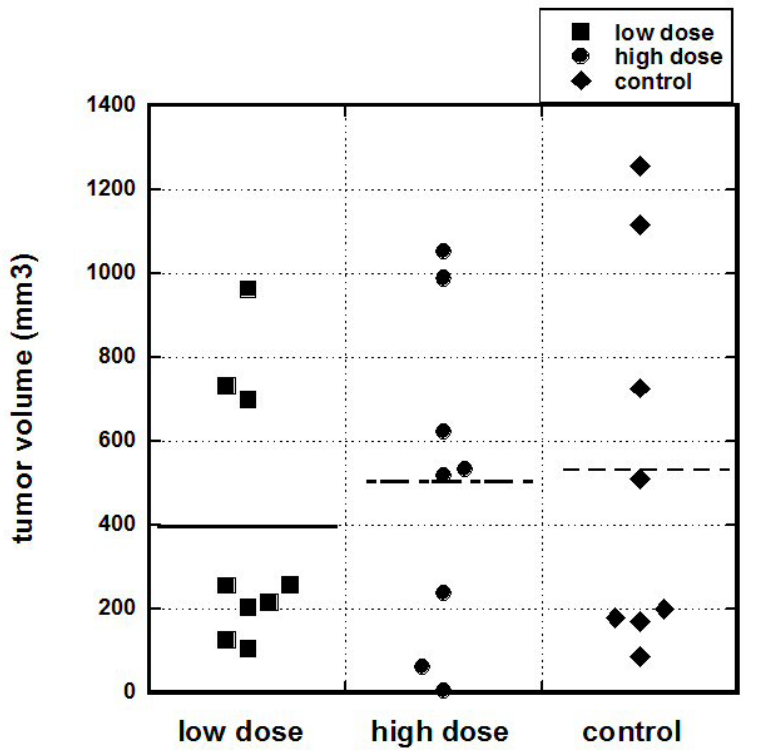

Figure 1a. S180 tumor volumes 21 days post implantation for positive control and ascorbate treated mice (Low AA=0.214 mg/kg; High AA=0.714 mg/kg).

in ascorbate treated tumor cells compared to untreated controls. In each case (Low AA and High AA), the difference in the mean values compared to positive controls were statistically significant $(p=0.03$ and $p=0.04$, respectively).

There was also a roughly two-fold increase in NRF2 gene levels in treated tumor, and this was also statistically significant: comparison between positive control and Low AA means yielded a $p=0.07$, while comparison between control and High AA yielded a $p=0.03$. When the treated values were pooled and compared to controls, the mean was 2.5 times higher with a p-value of 0.02 . NRF2 up-regulates apoptosis, so this result, taken with the results for p53, suggests that ascorbate therapy might increase the likelihood of programed cell death in tumor cells.

TERT, which affects telomerase, was also elevated in ascorbate treated tumors ( $p<0.03$ between High AA and control) while DNMT1, 


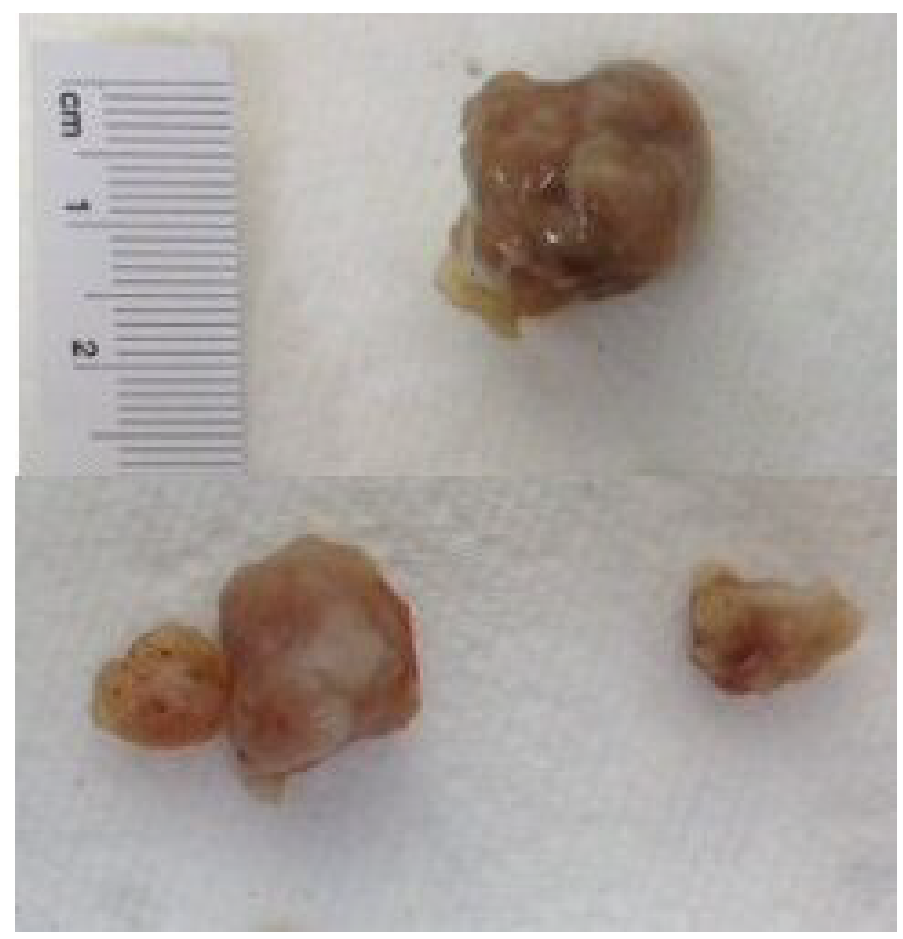

Figure 1b. Representative images of the tumors.

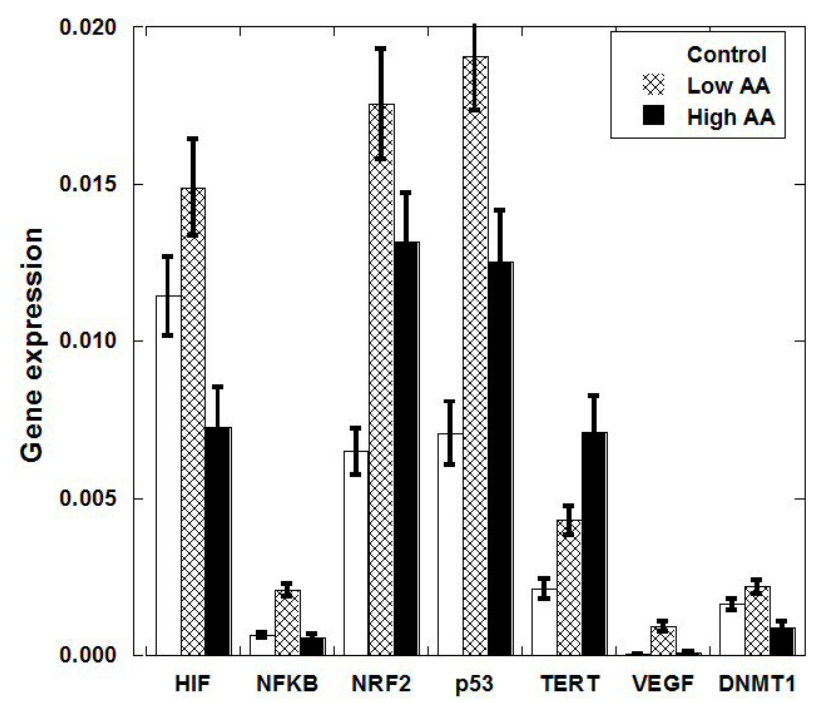

Figure 2. Mean ( $\pm \mathrm{SE}$ ) gene expression levels (normalized to housekeeping genes) in S180 tumors of untreated and ascorbate treated (Low AA $=0.214 \mathrm{mg} / \mathrm{kg}$; Max AA $=0.714 \mathrm{mg}$ / $\mathrm{kg})$ mice.

which is involved in DNA methylation, was reduced significantly $(p<0.03)$ in High AA treated tumors compared to controls. When results for Low AA and High AA are pooled, we find significant differences in expression, compared to positive controls, for p53 $(p<0.02)$, NRF2 $(p<0.01)$, TERT $(p<0.03)$, and DNMT1 $(p<0.05)$ using the Mann-Whitney $\mathrm{U}$ test.

We examined a possible correlation between gene expression and tumor size. Results for HIF, NF- $\mathrm{B}$, and p53, are shown in Figure 4.

Clearly larger tumors showed elevated levels of HIF and NF- $\kappa B$ and lower levels of p53 compared to smaller tumors. Using a cut-off of $600 \mathrm{~mm}^{3}$, we measured the fractional change in expression (from small to large) for six genes (VEGF was under-expressed in all analyzed samples and was not included). This is shown in Table 2. For untreated mice, increases in tumor size increased HIF and NF- $\mathrm{kB}$ expression by roughly $200 \%$, while ascorbate treatments eliminated this effect.

\section{Gene expression in kidney and liver}

To investigate the potential effect of tumor development on kidney and liver gene expression, we analyzed liver and kidney tissue from tumor bearing and tumor-free mice for gene expression levels. In particular, the ratio of gene expression in tumor bearing mice to that in tumor-free mice (Group B-Negative control, as described in Methods) is shown for kidney in Figure 5.

In liver, gene expression was generally similar to that in tumor-free mice (data are not shown) and was largely unaffected by treatment. The exception to this was TERT, which was elevated nearly four-fold (above tumor-free controls) in untreated mice, but was only mildly elevated in ascorbate treated mice.

NRF2 and p53 genes measured in kidney tissue were also above normal in tumor bearing mice, while no noticeable difference was observed in HIF and NF-kB and a moderate decrease was observed in DNMT genes.

Table 2. Average (Mean \pm SE) normalized gene expression levels in tumors from S180inoculated CD-1 mice. Positive control (S180, no AA) mice compared with those given Low AA treatment $(0.214 \mathrm{mg} / \mathrm{g})$ and High AA treatment $(0.714 \mathrm{mg} / \mathrm{g}) 3 \times$ weekly.

\begin{tabular}{|l|l|l|l|l|l|l|}
\hline \multicolumn{1}{|c|}{ Gene } & \multicolumn{2}{|c|}{$\begin{array}{c}\text { Mean } \pm \text { SE } \\
\text { Low AA }\end{array}$} & \multicolumn{2}{c|}{$\begin{array}{c}\text { Mean } \pm \text { SE } \\
\text { High AA }\end{array}$} & \multicolumn{2}{|c|}{$\begin{array}{c}\text { Mean } \pm \text { SE } \\
\text { Non-treated positive } \\
\text { control, S180 }\end{array}$} \\
\hline & Average & SE & Average & SE & Average & SE \\
\hline HIF & 0.01488 & 0.00153 & 0.00725 & 0.00127 & 0.01143 & 0.00124 \\
\hline NFKB & 0.00208 & 0.00019 & 0.00057 & 0.00013 & 0.00063 & 0.00008 \\
\hline NRF2 & 0.01754 & 0.00174 & 0.01316 & 0.00157 & 0.00649 & 0.00074 \\
\hline p53 & 0.01906 & 0.00171 & 0.01252 & 0.00165 & 0.00708 & 0.00100 \\
\hline TERT & 0.00429 & 0.00046 & 0.00710 & 0.00115 & 0.00213 & 0.00033 \\
\hline VEGF & 0.00093 & 0.00015 & 0.00010 & 0.00005 & 0.00006 & 0.00005 \\
\hline DNMT1 & 0.00219 & 0.00021 & 0.00090 & 0.00020 & 0.00163 & 0.00019 \\
\hline
\end{tabular}

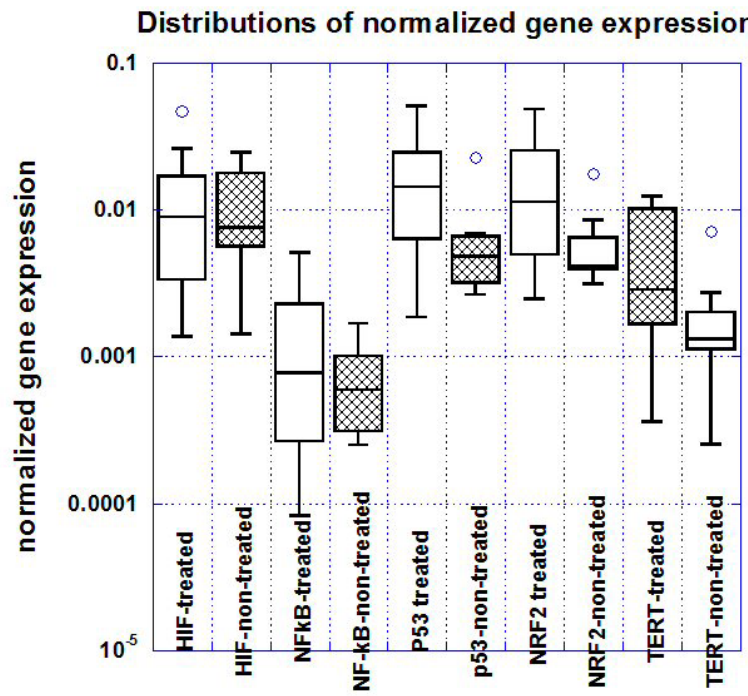

Figure 3. Box plots for gene expression levels (normalized to housekeeping genes) in S180 tumors of untreated and ascorbate treated mice (Low AA and High AA treated mice are pooled together). 
Table 3. Relative gene expression in large $\left(>600 \mathrm{~mm}^{3}\right)$ compared to small $\left(<600 \mathrm{~mm}^{3}\right)$ tumors, with percentage of differences in expression $\left(\mathrm{E}_{\text {large }}\right.$ minus $\mathrm{E}_{\text {small }}$, divided $\left.\mathrm{E}_{\text {small }}\right)$.

\begin{tabular}{|c|c|c|c|c|c|}
\hline Gene & Tumor size & Untreated control & Low dose AA & High dose AA & Average treated \\
\hline \multirow[t]{3}{*}{ p53 } & $<600 \mathrm{~mm}^{2}$ & 0.00875 & 0.01640 & 0.01272 & 0.01456 \\
\hline & $>600 \mathrm{~mm}^{2}$ & 0.00289 & 0.01436 & 0.01233 & 0.01335 \\
\hline & $\%$ of difference & -67 & -12.4 & -3.0 & -8.3 \\
\hline \multirow[t]{3}{*}{ NF-kB } & $<600 \mathrm{~mm}^{2}$ & 0.00044 & 0.00325 & 0.00072 & 0.00199 \\
\hline & $>600 \mathrm{~mm}^{2}$ & 0.00134 & 0.00215 & 0.00081 & 0.00148 \\
\hline & $\%$ of difference & 207.7 & -33.9 & 12.2 & -25.5 \\
\hline \multirow[t]{3}{*}{ HIF } & $<600 \mathrm{~mm}^{2}$ & 0.00691 & 0.01874 & 0.00903 & 0.01389 \\
\hline & $>600 \mathrm{~mm}^{2}$ & 0.02272 & 0.00287 & 0.00369 & 0.00328 \\
\hline & $\%$ of difference & 228.7 & -84.7 & -59.2 & -76.4 \\
\hline \multirow[t]{3}{*}{ NRF2 } & $<600 \mathrm{~mm}^{2}$ & 0.00752 & 0.01981 & 0.01093 & 0.01537 \\
\hline & $>600 \mathrm{~mm}^{2}$ & 0.00391 & 0.00379 & 0.01763 & 0.01071 \\
\hline & $\%$ of difference & -48.0 & -80.9 & 61.4 & -30.3 \\
\hline \multirow[t]{3}{*}{ TERT } & $<600 \mathrm{~mm}^{2}$ & 0.00267 & 0.00299 & 0.00551 & 0.00425 \\
\hline & $>600 \mathrm{~mm}^{2}$ & 0.00078 & 0.00243 & 0.01184 & 0.00714 \\
\hline & $\%$ of difference & -70.6 & -18.6 & 114.7 & 67.8 \\
\hline \multirow[t]{3}{*}{ DNMT1 } & $<600 \mathrm{~mm}^{2}$ & 0.00159 & 0.00203 & 0.00050 & 0.00127 \\
\hline & $>600 \mathrm{~mm}^{2}$ & 0.00174 & 0.00464 & 0.00129 & 0.00296 \\
\hline & $\%$ of difference & 9.4 & 128.0 & 153.2 & 133.0 \\
\hline
\end{tabular}

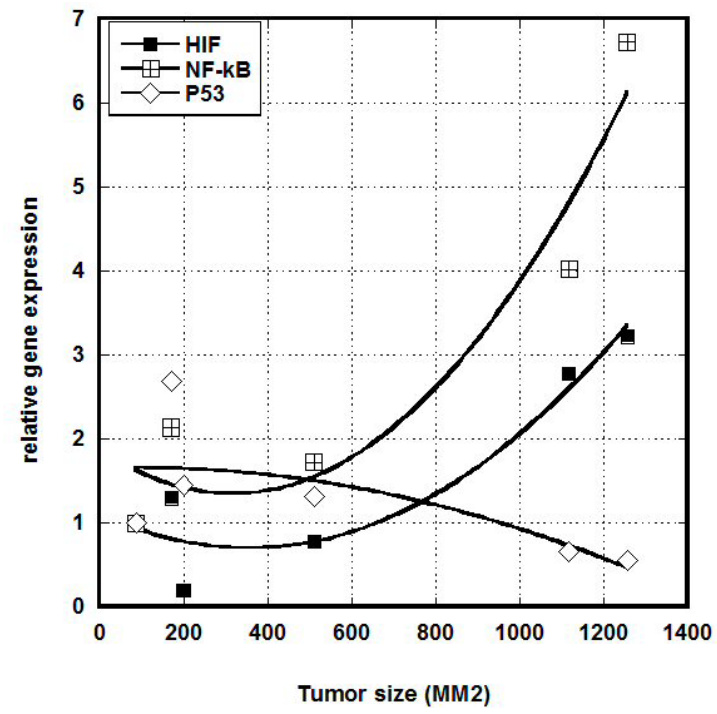

Figure 4. Effect of tumor size on HIF, NF-kB and $\mathrm{p} 53$ gene expression, in untreated positive control mice. Gene expression is normalized to the expression at the lowest volume of tumor.

For untreated tumors, we also examined the effect of tumor size on kidney gene expression (not shown). For NRF2 and p53 genes, the relative expression (compared to tumor-free controls) was roughly 3.0 for mice with $200 \mathrm{~mm}^{3}$ tumors, but reduced to roughly 0.9 for mice with tumors above $600 \mathrm{~mm}^{3}$. For HIF, relative gene expression increased with increasing tumor size, rising from roughly 0.5 for mice with $200 \mathrm{~mm}^{3}$ tumors to values of roughly 1.2 for tumors above mice with $600 \mathrm{~mm}^{3}$.

Finally, we examined the effect of metastasis on gene expression. Several mice developed metastases during this study; for example, three
Table 4. Ratio of gene expression in animals with metastatic tumors to gene expressions in those with localized tumors only. Values are averages for mice in the High AA dose group.

\begin{tabular}{|c|c|c|c|}
\hline Gene & \multicolumn{3}{|c|}{ Gene expression ratio } \\
\hline & Tumor & Kidney & Liver \\
\hline HIF & 3.64 & 1.24 & 1.67 \\
\hline NF-kB & 4.16 & 2.04 & 2.83 \\
\hline NRF2 & 0.43 & 0.68 & 1.61 \\
\hline p53 & 0.29 & 0.68 & 1.61 \\
\hline TERT & 0.17 & 0.10 & 0.44 \\
\hline DNMT1 & 3.78 & 3.78 & 2.12 \\
\hline
\end{tabular}

mice in a group of eight given High AA doses developed metastases, as did two of twelve mice given Low AA treatments. For mice given the high AA dose, ratios of gene expression (mean) in mice with metastases to gene expression (mean) for mice without metastases are given in Table 4. According to these data, in tumor samples of animals that developed metastasis the HIF, DNMT1, and NF- $\mathrm{BB}$ were roughly four times higher, while p53 and NRF2 genes were 0.3- 0.4 times lower than in animals with primary tumors only. The same tendency was found in liver and kidney samples.

\section{Conclusions}

We examined the effects of ascorbate therapy in CD1 mice with aggressive S180 tumors. Our data did not demonstrate a significant effect of ascorbate on tumor size, but did indicate some effects on gene expression. Average size of tumors for animals that developed tumor was $396 \pm 300$ for group C (low ascorbate), $502 \pm 390$ for group D (high ascorbate) and $530 \pm 450$ for group $\mathrm{E}$ (non-treated positive control). The group treated by high-doses of AA did not show statistical significant reduction of tumors in comparison with non-treated group and the average volumes of tumors were similar. 


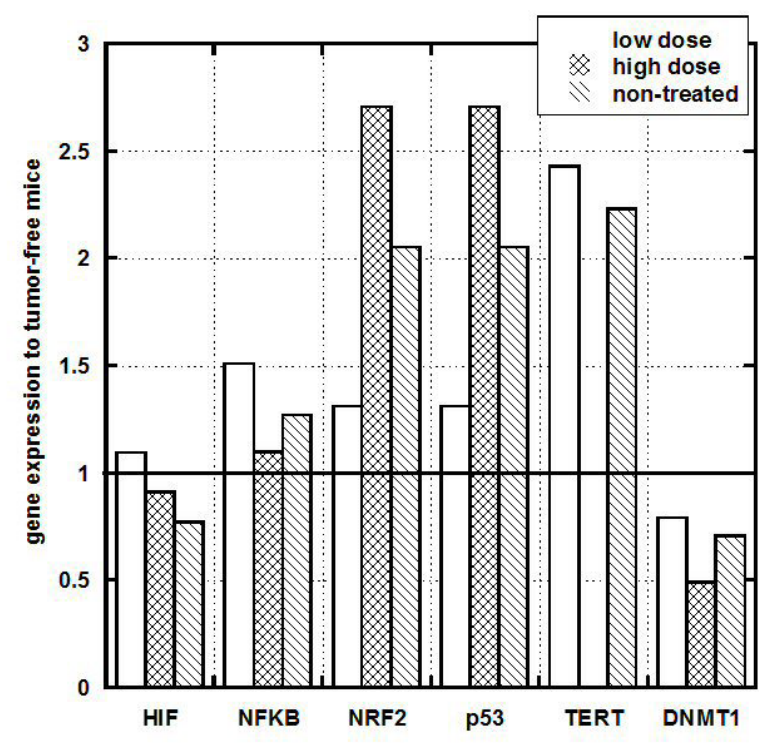

Figure 5. Gene expression in kidney cells of tumor bearing mice (treated or untreated). Values expressed as ratios to those in mice without tumors (negative control).

Ascorbate therapy significantly increased expression of tumor suppressor genes p53.

In group of mice treated by AA the expression of $\mathrm{p} 53$ was increased 2.7 fold for low AA treatment and 1.8 fold for group treated by high dose AA in comparison with non-treated positive control group. The results of the study have demonstrated that treatment by ascorbic acid causes to expand p53 tumor suppressive functions.

As ascorbic acid is anti-oxidant and has ability to suppress DNA damage and genomic instability mediated by reactive oxygen species (ROS) [91], we expected that HIF gene expression would be affected by ascorbic acid treatment. The above data show potential effects of ascorbate on HIF expression. The experimental data showed, that the maximum ascorbate dose tested $(0.714 \mathrm{mg} / \mathrm{g})$ reduced expression of the tumor promoting gene HIF. The level of mRNA expression in tumor samples in group treated by this dose of AA was 0.6 fold lower in comparison with non-treated positive control. There was no suppression of HIF-1 in group treated by low dose of AA.

We observed that HIF expression is highly dependent upon tumor size, being over twice as high in mice with large tumors than with mice bearing smaller tumors. This result correlates with the fact that HIF1 expression is induced by hypoxia and is typically overexpressed in tumors [82-84]. Expression of HIF was 200\% higher in larger tumors $\left(>600 \mathrm{~mm}^{3}\right)$ in comparison with smaller tumors $\left(<600 \mathrm{~mm}^{3}\right)$ for nontreated animals, and the level of mRNA of HIF-1 was decreased for larger tumors in ascorbic acid treated animals on $60 \%-80 \%$. As the result, in mice treated with ascorbate, the increase in HIF expression with tumor size was suppressed (Table 4).

We also founded that HIF mRNA detected in the liver was reduced in groups of mice treated with ascorbate, relative to untreated controls (0.7-0.8 fold).

Our previous research suggests that ascorbate therapy, at the high doses associated with intravenous infusions clinically, can inhibit angiogenesis and reduce tumor inflammation $[3,4,17,18]$. In study [92], lung blood vessel proliferation and the incidence of pulmonary malignant tumors were reduced in the offspring of mice expose to cigarette smoke and a preventive treatment with ascorbic acid in drinking water throughout the pregnancy. We expected therefore, to see the effects on HIF genes involved in angiogenesis promotion, and the gene for NF- $\mathrm{kB}$, a critical factor in inflammation. We did not observe systematic effect of ascorbate therapy on NF- $\kappa B$. One possible explanation is that our tumor model, with over $10^{6} \mathrm{~S} 180$ cells injected into the mice, was too fast acting and too aggressive for ascorbate therapy to slow down or significantly alter. The other possibility was that ascorbic acid levels in tumors did not reach pharmacological concentrations capable to produce the expected results in such a short time acting only as an antioxidant ROS scavenger as reported in study [93]. Tumors varied substantially in size, but grew so quickly and had such a deleterious effect on animal health that our animals needed to be euthanized after only a few weeks. Our hope for future experiment would be to use a slower growing tumor model, in which ascorbate therapy can be tested over a longer period of time. Another approximation would be to analyze the combination of ascorbic acid with a synergistic compound as in study [94] to evaluate the effect on tumor development and gene expression.

However, the dependence of gene expression on the size of tumors and the effect of ascorbic acid treatment on gene expression were found for NK- $\kappa B$ (Table 3). NF- $\kappa B$ expression was increased for larger tumors in positive control group on $200 \%$ and decreased in ascorbic acid treated animals on average $25 \%$.

In tumor bearing mice, p53 gene expression was elevated in kidneys, but normal in liver. Compared to untreated tumor-bearing mice, we found a statistically significant increase in expression of gene p53 $(p<0.02)$ in tumor-bearing mice treated with ascorbate. This is consistent with reports in the literature of ascorbate's effect on the p53 gene $[30,64,80]$. Our data showed that p53 gene expression was elevated in ascorbate treated groups of mice with tumors, tended to decrease as tumors became larger and was reduced in animals with metastatic tumors. Taken together, the data suggest that p53 gene expression decreases in large and metastatic tumors, but can be upregulated by ascorbate therapy.

The role of $\mathrm{p} 53$ as a tumor suppressor has been extensively studied [66-70]. It is estimated that roughly half of all tumor cell types harbor mutations in the p53 gene, and in most of the remaining cancers the gene is inactivated by a variety of mechanisms. Reactivation of p53 is an important strategy for inhibiting tumor growth and proliferation. It is typically activated in response to stress signals and transcriptionally induces a lot of target genes relevant to cell cycle progression, DNA repair, apoptosis, and tumor cell metabolism. The evidence presented above, that ascorbate may activate p53 expression in tumor cells, is encouraging and warrants further study.

Ascorbic acid treatment increased expression of NRF2 in both groups of treated animals in comparison with non-treated group. The role of NRF2 in carcinogenesis and cancer is still actively disputed and remains unresolved. There is abundant evidence that activation of NRF2 can suppress carcinogenesis, especially in its earliest stages. The current thinking is that NRF2 activity may be desirable in early stages of tumorigenesis, when the host is seeking to control premalignant carcinogenesis, but may be undesirable in later stages, when it could make fully malignant cancer cells become resistant to treatment $[85,86]$. In our model, with treatments beginning one week after tumor inoculation, the tumors may be already established, so that the analysis of the changes in NRF2 expression accompanying ascorbate therapy 
might have been more beneficial if the treatments were started earlier.

Comparison of the expression of DNMT1 in treated by AA and non-treated groups showed that high dose AA downregulated DNMT1 in tumor tissue 0.5 folds and there was no suppression by low dose AA. The same result was found for kidney tissues.

Expression of DNMTs in cancer and DNA methylation patterns in tumor cells in comparison to those of normal cells were analyzed in numerous studies and it was postulated that in most of the carcinogenesis DNMTs are over expressed [87-90]. Excessive amounts of DNMT1 may participate in the de novo methylation of $\mathrm{CpG}$ islands that are not methylated in normal cells and contribute to tumor development through $\mathrm{CpG}$ island methylation-mediated gene inactivation. Interestingly, two converse trends of DNA methylation changes were observed in many tumors. On the one hand, promoters of tumor suppressor genes are often hypermethylated leading to the silencing of the genes. On the other hand, the activity of DNMT1 is increased leading to DNA hypermethylation. Inactivation of tumor suppressor genes is central to the development of all common forms of human cancer.

TERT is involved in telomerase, which is thought to aid tumor cell growth and allow tumor cells to become immortal, so that TERT expression is considered a potential target for anticancer therapy.

In our study, expression of TERT was increased in tumor tissue for treated groups in comparison with non-treated group (2.0 folds for low dose AA and 3.3 for high dose AA). In kidney tissue overexpression of TERT was not found and there was suppression of TERT in liver tissue for groups treated by AA ( 0.5 folds for low dose and 0.45 fold for high dose).

Comparison of the gene expression in mice that developed metastasis with mice having localized tumors, showed that in animals that developed metastasis the HIF and NF- $\mathrm{kB}$ were 3.6-4 times higher, p53 and NRF2 were 0.4 and 0.3 times lower and DNMT1 was 3.8 times higher. The same tendency was found in liver and kidney samples of these two groups of mice.

In summary, the results of our study demonstrated that ascorbate therapy had effect on the expression of several genes relevant to the development or inhibition of cancer. Reduced expression of such tumor promoting genes as HIF and increased expression of tumor suppression genes such as $\mathrm{p} 53$ support the hypothesis that AA can act as potential agents for the suppression of tumor development. To obtain a better knowledge of the AA effect in gene expression and tumor development and metastasis, further studies should be done with less aggressive course of tumor development and a larger number of cancer related genes.

\section{Acknowledgements}

The study was supported by Flossie E West Memorial Trust.

\section{References}

1. Levy TE (2012) Primal panacea. MedFox Publishing

2. Hartel C, Puzik A, Gopel W, Temming P, Bucsky P, et al. (2007) Immunomodulatory effect of vitamin $\mathrm{C}$ on intracytoplasmic cytokine production in neonatal cord blood cells. Neonatology 91: 54-60. [Crossref]

3. Mikirova N, Casciari J, Rogers A, Taylor P (2012) Effect of high-dose intravenous vitamin C on inflammation in cancer patients. J Transl Med 10: 189. [Crossref]

4. Mikirova N, Rogers A, Casciari J, Taylor P (2012) Effect of high dose intravenous ascorbic acid on the level of inflammation in patients with rheumatoid arthritis. Modern Research in Inflammation 1: 26-32.
5. Ichim TE, Minev B, Braciak T, Luna B, Hunninghake R, et al. (2011) Intravenous ascorbic acid to prevent and treat cancer-associated sepsis? J Transl Med 9: 25. [Crossref]

6. Härtel C, Strunk T, Bucsky P, Schultz C (2004) Effects of vitamin C on intracytoplasmic cytokine production in human whole blood monocytes and lymphocytes. Cytokine 27: 101-106. [Crossref]

7. de la Fuente M, Ferrández MD, Burgos MS, Soler A, Prieto A, et al. (1998) Immune function in aged women is improved by ingestion of vitamins C and E. Can J Physiol Pharmacol 76: 373-380. [Crossref]

8. Vojdani A, Ghoneum M (1993) In vivo effect of ascorbic acid on enhancement of human natural killer cell activity. Nutr Res 13: 753-754.

9. Ohno S, Ohno Y, Suzuki N, Soma G, Inoue M (2009) High-dose vitamin C (ascorbic acid) therapy in the treatment of patients with advanced cancer. Anticancer Res 29: 809-815. [Crossref]

10. Parrow NL, Leshin JA, Levine M (2013) Parenteral Ascorbate As a Cancer Therapeutic: A Reassessment Based on Pharmacokinetics. Antioxid Redox Signal 19: 2141-2156. [Crossref]

11. Du J, Cullen JJ, Buettner GR (2012) Ascorbic acid: chemistry, biology and the treatment of cancer. Biochim Biophys Acta 1826: 443-457. [Crossref]

12. Jacobs C, Hutton B, Ng T, Shorr R, Clemons M (2015) Is there a role for oral or intravenous ascorbate (vitamin $\mathrm{C}$ ) in treating patients with cancer? A systematic review. Oncologist 20: 210-223. [Crossref]

13. McCORMICK WJ (1954) Cancer: the preconditioning factor in pathogenesis; a new etiologic approach. Arch Pediatr 71: 313-322. [Crossref]

14. Herberman R (1983) Possible role of natural killer cells in host resistance against tumors and diseases. Clin Immunol Allergy 3: 479-485.

15. Wilson MK, Baguley BC, Wall C, Jameson MB, Findlay MP (2014) Review of highdose intravenous vitamin $\mathrm{C}$ as an anticancer agent. Asia Pac J Clin Oncol 10: 22-37. [Crossref]

16. Riordan NH, Riordan HD, Meng X, Li Y, Jackson JA (1995) Intravenous ascorbate as a tumor cytotoxic chemotherapeutic agent. Med Hypotheses 44: 207-213. [Crossref]

17. Mikirova NA, Ichim TE, Riordan NH (2008) Anti-angiogenic effect of high doses of ascorbic acid. J Transl Med 6: 50. [Crossref]

18. Mikirova NA, Casciari JJ, Riordan NH (2010) Ascorbate inhibition of angiogenesis in aortic rings ex vivo and subcutaneous Matrigel plugs in vivo. $J$ Angiogenes Res 2: 2. [Crossref]

19. Casciari JJ, Riordan NH, Schmidt TL, Meng XL, Jackson JA, et al. (2001) Cytotoxicity of ascorbate, lipoic acid, and other antioxidants in hollow fibre in vitro tumours. $\mathrm{Br} J$ Cancer 84: 1544-1550. [Crossref]

20. Chen Q, Espey MG, Krishna MC, Mitchell JB, Corpe CP, et al. (2005) Pharmacologic ascorbic acid concentrations selectively kill cancer cells: action as a pro-drug to deliver hydrogen peroxide to tissues. Proc Natl Acad Sci U S A 102: 13604-13609. [Crossref]

21. Du J, Martin SM, Levine M, Wagner BA, Buettner GR, et al. (2010) Mechanisms of ascorbate-induced cytotoxicity in pancreatic cancer. Clin Cancer Res 16: 509-520. [Crossref]

22. Chen Q, Espey MG, Sun AY, Lee JH, Krishna MC, et al. (2007) Ascorbate in pharmacologic concentrations selectively generates ascorbate radical and hydrogen peroxide in extracellular fluid in vivo. Proc Natl Acad Sci USA 104: 8749-8754. [Crossref]

23. Sinnberg T, Noor S, Venturelli S, Berger A, Schuler P, et al. (2014) The ROS-induced cytotoxicity of ascorbate is attenuated by hypoxia and HIF-1alpha in the NCI60 cancer cell lines. J Cell Mol Med 18: 530-541. [Crossref]

24. Chen Q, Espey MG, Sun AY, Pooput C, Kirk KL, et al. (2008) Pharmacologic doses of ascorbate act as a prooxidant and decrease growth of aggressive tumor xenografts in mice. Proc Natl Acad Sci U S A 105: 11105-11109. [Crossref]

25. Yeom CH, Lee G, Park JH, Yu J, Park S, et al. (2009) High dose concentration administration of ascorbic acid inhibits tumor growth in BALB/C mice implanted with sarcoma 180 cancer cells via the restriction of angiogenesis. J Transl Med 7: 70 [Crossref]

26. Pollard HB, Levine MA, Eidelman O, Pollard M (2010) Pharmacological ascorbic acid suppresses syngeneic tumor growth and metastases in hormone-refractory prostate cancer. In Vivo 24: 249-255. [Crossref]

27. Frömberg A, Gutsch D, Schulze D, Vollbracht C, Weiss G, et al. (2011) Ascorbate 
exerts anti-proliferative effects through cell cycle inhibition and sensitizes tumor cells towards cytostatic drugs. Cancer Chemother Pharmacol 67: 1157-1166. [Crossref]

28. Campbell A, Jack T (1979) Acute reactions to mega ascorbic acid therapy in malignant disease. Scott Med J 24: 151-153. [Crossref]

29. Prasad KN, Hernandez C, Edwards-Prasad J, Nelson J, Borus T, et al. (1994) Modification of the effect of tamoxifen, cis-platin, DTIC, and interferon-alpha $2 \mathrm{~b}$ on human melanoma cells in culture by a mixture of vitamins. Nutr Cancer 22: 233-245. [Crossref]

30. Reddy VG, Khanna N, Singh N (2001) Vitamin C augments chemotherapeutic response of cervical carcinoma HeLa cells by stabilizing P53. Biochem Biophys Res Commun 282: 409-415. [Crossref]

31. Prasad KN, Sinha PK, Ramanujam M, Sakamoto A (1979) Sodium ascorbate potentiates the growth inhibitory effect of certain agents on neuroblastoma cells in culture. Proc Natl Acad Sci U S A 76: 829-832. [Crossref]

32. Espey MG, Chen P, Chalmers B, Drisko J, Sun AY, et al. (2011) Pharmacologic ascorbate synergizes with gemcitabine in preclinical models of pancreatic cancer. Free Radic Biol Med 50: 1610-1619. [Crossref]

33. Abdel-Latif MM, Raouf AA, Sabra K, Kelleher D, Reynolds JV (2005) Vitamin C enhances chemosensitization of esophageal cancer cells in vitro. J Chemother 17: 539549. [Crossref]

34. Verrax J, Calderon PB (2009) Pharmacologic concentrations of ascorbate are achieved by parenteral administration and exhibit antitumoral effects. Free Radic Biol Med 47: 32-40. [Crossref]

35. Ma Y, Chapman J, Levine M, Polireddy K, Drisko J, et al. (2014) High-dose parenteral ascorbate enhanced chemosensitivity of ovarian cancer and reduced toxicity of chemotherapy. Sci Transl Med 6: 222ra18. [Crossref]

36. Stephenson CM, Levin RD, Spector T, Lis CG (2013) Phase I clinical trial to evaluate the safety, tolerability, and pharmacokinetics of high-dose intravenous ascorbic acid in patients with advanced cancer. Cancer Chemother Pharmacol 72: 139-146. [Crossref]

37. Monti DA, Mitchell E, Bazzan AJ, Littman S, Zabrecky G, et al. (2012) Phase I evaluation of intravenous ascorbic acid in combination with gemcitabine and erlotinib in patients with metastatic pancreatic cancer. PLoS One 7: e29794. [Crossref]

38. Riordan HD, Casciari JJ, González MJ, Riordan NH, Miranda-Massari JR, et al. (2005) A pilot clinical study of continuous intravenous ascorbate in terminal cancer patients. $P$ $R$ Health Sci J 24: 269-276. [Crossref]

39. Welsh JL, Wagner BA, van't Erve TJ, Zehr PS, Berg DJ, et al. (2013) Pharmacological ascorbate with gemcitabine for the control of metastatic and node-positive pancreatic cancer (PACMAN): results from a phase I clinical trial. Cancer Chemother Pharmacol 71: 765-775. [Crossref]

40. Vollbracht C, Schneider B, Leendert V, Weiss G, Auerbach L, et al. (2011) Intravenous vitamin $\mathrm{C}$ administration improves quality of life in breast cancer patients during chemo-/radiotherapy and aftercare: Results of a retrospective, multicentre, epidemiological cohort study in Germany. In Vivo 25: 983-990. [Crossref]

41. Semenza GL (2003) Targeting HIF-1 for cancer therapy. Nat Rev Cancer 3: 721-732. [Crossref]

42. Semenza GL (2001) HIF-, O(2), and the 3 PHDs: how animal cells signal hypoxia to the nucleus. Cell 107: 1-3. [Crossref]

43. Kimura H, Weisz A, Ogura T, Hitomi Y, Kurashima Y, et al. (2001) Identification of hypoxia-inducible factor 1 ancillary sequence and its function in vascular endothelial growth factor gene induction by hypoxia and nitric oxide. J Biol Chem 276: 2292-2298. [Crossref]

44. Brennan PA, Umar T, Smith GI, Lo CH, Tant S (2002) Expression of nitric oxide synthase-2 in cutaneous squamous cell carcinoma of the head and neck. Br J Oral Maxillofac Surg 40: 191-194. [Crossref]

45. Wang Y, Liu Y, Malek SN, Zheng P, Liu Y (2011) Targeting HIF1 $\alpha$ eliminates cancer stem cells in hematological malignancies. Cell Stem Cell 8: 399-411. [Crossref]

46. Deeb G, Vaughan MM, McInnis I, Ford LA, Sait SN, et al. (2011) Hypoxia-inducible factor-1 $1 \hat{\mathrm{I}} \pm$ protein expression is associated with poor survival in normal karyotype adult acute myeloid leukemia. Leuk Res 35: 579-584. [Crossref]

47. Wellmann S, Guschmann M, Griethe W, Eckert C, von Stackelberg A, et al. (2004) Activation of the HIF pathway in childhood ALL, prognostic implications of VEGF. Leukemia 18: 926-933. [Crossref]
48. Glaser SP, Lee EF, Trounson E, Bouillet P, Wei A, et al. (2012) Anti-apoptotic Mcl-1 is essential for the development and sustained growth of acute myeloid leukemia. Genes Dev 26: 120-125. [Crossref]

49. Del Principe MI, Del Poeta G, Venditti A, Buccisano F, Maurillo L, et al. (2005) Apoptosis and immaturity in acute myeloid leukemia. Hematology 10: 25-34. [Crossref]

50. Broome HE, Yu AL, Diccianni M, Camitta BM, Monia BP, et al. (2002) Inhibition of Bcl-xL expression sensitizes T-cell acute lymphoblastic leukemia cells to chemotherapeutic drugs. Leuk Res 26: 311-316. [Crossref]

51. Gao P, Zhang H, Dinavahi R, Li F, Xiang Y, et al. (2007) HIF-dependent antitumorigenic effect of antioxidants in vivo. Cancer Cell 12: 230-238. [Crossref]

52. Braun T, Carvalho G, Fabre C, Grosjean J, Fenaux P, et al. (2006) Targeting NFkappaB in hematologic malignancies. Cell Death Differ 13: 748-758. [Crossref]

53. Karin M, Cao Y, Greten FR, Li ZW (2002) NF-kappaB in cancer: from innocent bystander to major culprit. Nat Rev Cancer 2: 301-310. [Crossref]

54. Gilmore TD, Koedood M, Piffat KA, White DW (1996) Rel/NF-kappaB/IkappaB proteins and cancer. Oncogene 13: 1367-1378. [Crossref]

55. Aggarwal BB, Sethi G, Nair A, Ichikawa H (2006) Nuclear Factor-kB: A Holy Grail in Cancer Prevention and Therapy. Current Signal Transduction Therapy 1: 25-52.

56. Reikvam H, Olsnes AM, Gjertsen BT, Ersvar E, Bruserud Ø (2009) Nuclear factorkappaB signaling: a contributor in leukemogenesis and a target for pharmacological intervention in human acute myelogenous leukemia. Crit Rev Oncog 15: 1-41. [Crossref]

57. Cárcamo JM, Pedraza A, Bórquez-Ojeda O, Zhang B, Sanchez R, et al. (2004) Vitamin $\mathrm{C}$ is a kinase inhibitor: dehydroascorbic acid inhibits IkappaBalpha kinase beta. Mol Cell Biol 24: 6645-6652. [Crossref]

58. Bowie AG, O'Neill LA (2000) Vitamin C inhibits NF-kappa B activation by TNF via the activation of $\mathrm{p} 38$ mitogen-activated protein kinase. J Immunol 165: 7180-7188. [Crossref]

59. Pathi SS, Lei P, Sreevalsan S, Chadalapaka G, Jutooru I, et al. (2011) Pharmacologic doses of ascorbic acid repress specificity protein (Sp) transcription factors and Spregulated genes in colon cancer cells. Nutr Cancer 63: 1133-1142. [Crossref]

60. Jutooru I, Chadalapaka G, Sreevalsan S, Lei P, Barhoumi R, et al. (2010) Arsenic trioxide downregulates specificity protein $(\mathrm{Sp})$ transcription factors and inhibits bladder cancer cell and tumor growth. Exp Cell Res 316: 2174-2188. [Crossref]

61. Jutooru I, Chadalapaka G, Lei P, Safe S (2010) Inhibition of NFkappaB and pancreatic cancer cell and tumor growth by curcumin is dependent on specificity protein downregulation. J Biol Chem 285: 25332-25344. [Crossref]

62. Jutooru I, Chadalapaka G, Abdelrahim M, Basha MR, Samudio I, et al. (2010) Methyl 2-cyano-3,12-dioxooleana-1,9-dien-28-oate decreases specificity protein transcription factors and inhibits pancreatic tumor growth: role of microRNA- 27a. Mol Pharmacol 78: 226-236. [Crossref]

63. Hahm E, Jin DH, Kang JS, Kim YI, Hong SW, et al. (2007) The molecular mechanism of vitamin C on cell cycle regulation in B16F10 murine melanoma. JCell Biochem 102: 1002-1010. [Crossref]

64. Kim JE, Jin DH, Lee SD, Hong SW, Shin JS, et al. (2008) Vitamin C inhibits p53induced replicative senescence through suppression of ROS production and p38 MAPK activity. Int J Mol Med 22: 651-655. [Crossref]

65. Lee SK, Kang JS, Jung da J, Hur DY, Kim JE, et al. (2008) Vitamin C suppresses proliferation of the human melanoma cell SK-MEL-2 through the inhibition of cyclooxygenase- (COX-2) expression and the modulation of insulin-like growth factor II (IGF-II) production. $J$ Cell Physiol 216: 180-188. [Crossref]

66. Muller PAJ, Vousden KH (2013) p53 mutations in cancer. Nature Cell Biology 15: 1-8

67. Riley T, Sontag E, Chen P, Levine A (2008) Transcriptional control of human p53regulated genes. Nat Rev Mol Cell Biol 9: 402-412. [Crossref]

68. Vogelstein B, Lane D, Levine AJ (2000) Surfing the p53 network. Nature 408: 307 310. [Crossref]

69. Vousden KH, Lane DP (2007) p53 in health and disease. Nat Rev Mol Cell Biol 8: 275-283. [Crossref]

70. Marchenko ND, Moll UM (2007) The role of ubiquitination in the direct mitochondrial death program of p53. Cell Cycle 6: 1718-1723. [Crossref]

71. Bashtrykov P, Jeltsch A. (2015) DNMT1-associated DNA methylation changes in cancer. 2015. Cell Cycle 14: 1-5. [Crossref] 
72. Robertson KD (2005) DNA methylation and human disease. Nat Rev Genet 6: 597-610. [Crossref]

73. Costello JF, Frühwald MC, Smiraglia DJ, Rush LJ, Robertson GP, et al. (2000) Aberrant CpG-island methylation has non-random and tumour-type-specific patterns. Nat Genet 24: 132-138. [Crossref]

74. Chan AO, Broaddus RR, Houlihan PS, Issa JP, Hamilton SR, et al. (2002) CpG island methylation in aberrant crypt foci of the colorectum. Am J Pathol 160: 1823-1830. [Crossref]

75. Laird PW (2003) The power and the promise of DNA methylation markers. Nat Rev Cancer 3: 253-266. [Crossref]

76. Baylin SB, Makos M, Wu JJ, Yen RW, de Bustros A, et al. (1991) Abnormal patterns of DNA methylation in human neoplasia: potential consequences for tumor progression. Cancer Cells 3: 383-390. [Crossref]

77. Qin Y, Guo H, Tang B, Yang SM (2014) The non-reverse transcriptase activity of the human telomerase reverse transcriptase promotes tumor progression (Review). Int $J$ Oncol 45: 525-531. [Crossref]

78. Sporn MB, Liby KT (2012) NRF2 and cancer: the good, the bad and the importance of context. Nat Rev Cancer 12: 564-571. [Crossref]

79. Kensler TW, Wakabayashi N (2010) Nrf2: friend or foe for chemoprevention? Carcinogenesis 31: 90-99. [Crossref]

80. Venturelli S, Sinnberg TW, Berger A, Noor S, Levesque MP3, et al. (2014) Epigenetic impacts of ascorbate on human metastatic melanoma cells. Front Oncol 4: 227. [Crossref]

81. Livak KJ, Schmittgen TD (2001) Analysis of relative gene expression data using realtime quantitative PCR and the 2(-Delta Delta C(T)) Method. Methods 25: 402-408. [Crossref]

82. Semenza GL (1999) Regulation of mammalian O2 homeostasis by hypoxia-inducible factor 1. Annu Rev Cell Dev Biol 15: 551-578. [Crossref]

83. Zhong H, DeMarzo AM, Laughner E, LimM, HiltonDA, et al. (1999) Overexpression of hypoxia-inducible factor 1alpha in common human cancers and their metastases. Cancer Res 59: 5830-5835. [Crossref]
84. Talks KL, Turley H, Gatter KC, Maxwell PH, PughCW, et al. (2000) The expression and distribution of the hypoxia-inducible factors HIF-1alpha and HIF-2alpha in normal human tissues, cancers, and tumor-associated macrophages. Am J Pathol 157: 411-421. [Crossref]

85. Hayes JD, McMahon M, Chowdhry S, Dinkova-Kostova AT (2010) Cancer chemoprevention mechanisms mediated through the Keap1-Nrf2 pathway. Antioxid Redox Signal 13: 1713-1748. [Crossref]

86. Hu R, Saw CL, Yu R, Kong AN (2010) Regulation of NF-E2-related factor 2 signaling for cancer chemoprevention: antioxidant coupled with antiinflammatory. Antioxid. Redox Signal 13: 1679-1698.

87. Robertson KD, Uzvolgyi E, Liang G, Talmadge C, Sumegi J, et al. (1999) The human DNA methyltransferases (DNMTs), 3a and 3b: coordinate mRNA expression in normal tissues and overexpression in tumors. Nucleic Acids Res 27: 2291-2298. [Crossref]

88. Siegfried Z, Cedar H (1997) DNA methylation: a molecular lock. Curr Biol 7: R305307. [Crossref]

89. Robertson KD, Jones PA (2000) DNA methylation: past, present and future directions Carcinogenesis 21: 461-467. [Crossref]

90. Tycko B (2000) Epigenetic gene silencing in cancer. J Clin Invest 105: 401-407. [Crossref]

91. Gao P, Zhang H, Dinavahi R, Li F, Xiang Y, et al. (2007) HIF-dependent antitumorigenic effect of antioxidants in vivo. Cancer Cell 12: 230-238. [Crossref]

92. De Flora S, Ganchev G, Iltcheva M, La Maestra S, Micale RT, et al. (2016) Pharmacological Modulation of Lung Carcinogenesis in Smokers: Preclinical and Clinical Evidence. Trends Pharmacol Sci 37: 120-142. [Crossref]

93. Kumar A, Singh B, Sharma PR, Bharate SB, Saxena AK, et al. (2016) A novel microtubule depolymerizing colchicine analogue triggers apoptosis and autophagy in HCT-116 colon cancer cells. Cell Biochem Funct 34: 69-81. [Crossref]

94. Nayak D, Minz AP, Ashe S, Rauta PR, Kumari M, et al. (2016) Synergistic combination of antioxidants, silver nanoparticles and chitosan in a nanoparticle based formulation: Characterization and cytotoxic effect on MCF-7 breast cancer cell lines. $J$ Colloid Interface Sci 470: 142-152. [Crossref]

Copyright: (C2016 Mikirova N. This is an open-access article distributed under the terms of the Creative Commons Attribution License, which permits unrestricted use, distribution, and reproduction in any medium, provided the original author and source are credited. 